\title{
Department of Reviews and Abstracts
}

Conducted by Hugo Ehreneest, M.D., Assuciate Eutrok

\section{Collective Review}

\author{
Five Year Radium Cures of Cervical Cancer \\ (Critical Review of Recent Literature)
}

By Fred. J. Taussia, M.D., F.A.C.S., St. Louis, Mo.

Sufficient time has now elapsed to form a tentative estimate of the value of radium as a curative agent in cervical cancer. As far back as 1914 a few cases were reported by Cheron and Duval; ${ }^{1}$ and Wickham and Degrais, ${ }^{2}$ that had remained cured for four years, but no systematic treatment on a largc scale was begun until the years 1913-1915. Those were the times when radium enthusiasm was at its height and we can now determine the final outcome of the cases treated during that period. 'That a large proportion of these reports emanate from Germany is to be explained chiefly on two grounds: The one is that German eities and iniversities purchased large quantities of radium and mesothorium for their clinics and hospitals in 1913; the other is that the German Gynecological Society at its meeting at Halle in 1913 decided to try out on a large scale the use of radium therapy in operable as well as inoperable cancer of the uterus and to report at the meeting two years later. The war came and not unfortunately interfered with premature reports of these results. A five year period has now elapsed and we can begin to form an estimate of the percentage of permanent cures obtained. Experience with the results of the radical hysterectomy of Wertheim already showed conclisively that it was necessary to wait five years before counting a case as cured. Even after that time an occasional recurrence would be found, but this was so exceptional that it did not materially influence the final percentages. The absolute cures by this radical hysterectomy averaged around 20 per cent, that is to say, one out of every five persons afflicted with cervical cancer could be saved by operation. It has been claimed by von Seuffert ${ }^{3}$ that recurrences following radium treatment do not appear later than three years after complete retrogression of the tumor, but the reports of Schaefer, ${ }^{4} \mathrm{Heyman}^{5}$ and others thoroughly disproved this. So we had better hold to the fivc-ycar period as the final test of treatment. It cannot be denied, however, that the percentage of late recurrences is distinctly less after radium treatment than after operation. In this review, therefore, I liave excluded those cases that had not been under observation a sufficient length of time. I also deducted all cancers of the uterine body, the urethra, and the vagina, since they demand separate consideration.

France, where radium was first discovered and used for the treatment of cancer, has produced no systematic study of five-year results. Degrais, ${ }^{6}$ who was associated with Wickham, did not, in his recent report, give detailed statisties. His experience dates back to 1908, but his article only contains general observations as to treatment. The supply of radium in France has 
always been limited, and the interest has centered more in dermatology than in gynecology.

From England we have the yearly reports of the Radium Institute, but there is no analysis of five year results, neither has any group of gynecologists specially interested itself in this form of treatment until recently.

Spain has produced in Recasens ${ }^{7}$ a radium enthusiast whose experience extends over a long period. One hundred (wenty-six of his cases date back to 1914-15 and thirty-two of them (25.4 per cent) are at the present time free of recurrence. He was one of the first to include operable as well as inoperable cases in his treatments.

In Sweden the institute at Stockholm purchased radium in 1913 and Heyman $^{5}$ has published carefully analyzed reports in 1917 and again in 1920 of the results of treatment in cervical cancer. Hansen ${ }^{8}$ also has written concerning the work of this institute. Of the cases dating back to $1914-15,66$ patients showed 18 cures of more than five years' duration. This high percentage of 27.3 per cent curability may be accounted for in part by a better technic, for Heyman emphasized the importance of a high intracervical application, heavy dosage, and a series of three treatments, all within five weeks' time. Most other clinics at that time gave more frequent lighter treatments at longer intervals and made vaginal applications. This points to the possibility of a considerable increase in the percentage of cures under improved radium technic in other clinies.

From Switzerland we have a report, though a somewhat meager one, from Hussy, ${ }^{9}$ of Basel, who found 3 cures out of 12 cases of cervical cancer treated longer than four years ago.

Germany furnishes the bulk of the evidence upon this subject and most of the reports appear in the transactions of the meeting of the German Gynecological Society held in Berlin, May 26-29, 1920. They include Schaefer ${ }^{4}$ (Berlin) 282 cases; von Seuffert ${ }^{3}$ (Munich) 205 cases; Warnekros ${ }^{10}$ (Berlin) 173 eases ; Flatau ${ }^{11}$ (Dresden) 25 cases ; Schweitzer ${ }^{12}$ (Leipzig) 49 cases; Weinbremner $^{13}$ (Magdeburg) 51 cases; Gieseke ${ }^{14}$ (Kiel) 39 eases; Baisch ${ }^{15}$ (Stuttgart) 42 cases; and Dietrich ${ }^{16}$ (Goettingen) 26 eases. From some clinics such as Eckelt ${ }^{17}$ (Frankfurt), Eijnar ${ }^{18}$ (Heidelberg), and Adler ${ }^{19}$ (Vienna) the reports available are too vague to be included in this summary. The accompanying table (Table 1) gives the essentials of these reports. The percentages of permanent cures it will be seen range from 10 to 20 per cent.

American literature thus far contributes but little to this subject. Kelly ${ }^{20}$ as far back as 1916 reported two cures, one of seven and one of five years' duration, but unfortunately he has not yet tabulated his five-year results, althongh he had treated 327 eases of uterine and vaginal cancer previous to April, 1916. Bailey ${ }^{21}$ from the General Memorial Hospital of New York presented in 1919 a review of 49 cases of cervical cancer treated in 1915 with but 4 persons free of recurrence. Only one operable case was included in this list and his technic during that period was far inferior to that now employed, which accounts for his low percentage of curability ( 8 per cent). The greatest enthusiast for radium treatment of cervical cancer is Ransahoff, ${ }^{22}$ who reports 3 cures out of 30 cases treated five years ago. Three additional cases of this series are free of recurrence two to four years after treatment. Schmitz ${ }^{2 s}$ reports 3 cases of cervical cancer treated with radium alune, cured for longer than 3 years, but he does not state what proportion of his 208 cases were treated during these first three years, hence no percentage can be figured out. Clark ${ }^{24}$ recently discussed the outcome of 209 cases treated between 191419. Practically all were inoperable. Out of 26 cervical cancers of over four years' duration, 3 were living and free of recurrence.

To obtain the absolute percentage of cures after radium treatment we must observe the same rigid rules that were laid down regarding the Wertheim 
operation. All cases that present themselves for treatment, whether treatment is given or not, must be included. No deductions can be allowed for those that do not follow up treatment after one application has been made, for especially in comparing radium treatment with operation it cannot be denied that the latter has a distinct advantage in that all the work is done at one time, whereas radium treatment often extends over a considerable period during which the patient may for one reason or another fail to return, thus interfering with the final outcome. Neither can we deduct intercurrent deaths during the five-year period, even where death was proved by autopsy to be due to other causes, for no autopsy is so perfect that it can detect microscopic remnants of cancer in lymph gland or connective tissue. All complete or partial hysterectomies, whether done before or after radiation, must be separately considered, and, of course, we must limit discussion solely to primary cancer of the cervix. I do not think it advisable, however, for the present to distinguish between eases where radium alone was used and those where $\mathrm{x}$-ray was given in addition. With such limitations 1 have been able to tabulate 1114 cases treated five or more years ago, of whom 223 are alive and free of recurrence. This means a curability of exactly 20 per cent, practically identical with the average results obtained by the radical hysterectomy.

We must bear in mind however when comparing the results of radium with those of operation, that the 20 to 25 per cent absolute curability by the radical operation comes after an experience of 15 to 20 years with this procedure during which time many improvements were devised to lower the primary mortality and decrease the likelihood of recurrence. The first results of Wertheim and others did not yield more than about 12 per cent absolute curability. A similar increase in cures is reasonably to be expected as a result of improved technic in radium treatment. In fact this has already been apparently obtained in two clinies which employed as early as 1914-15 methods of treatment similar to those now generally accepted as the best. It would seem therefore reasonably certain that in the future, if all cases of cervical cancer are included, radium alone will be found to cure more cases than operation alone.

The crux of the matter, however, as I see it, lies not in a comparison of all cases treated, but in a comparison of the operable cases alone. Not even the greatest skeptic can now deny that radium can cffcct a cure whcre operation is impossible. The percentages of cures in inoperable cancer of the cervix obtained in the larger clinies are: Schaefer 5.5 per cent, Warnekros 6 per cent, von Seuffert 8 per cent. Sume variation will doubtless be found as to the limits of operability, but in general this has been fairly well established by past experiences. If these extreme limits, including the so-called borderline cases as well as the readily operable ones, be accepted, in other words those in which the expert surgeon would do a hysterectomy, we have a sound basis for comparative statistics. It seems strange that von Seuffert in his detailed and otherwise logical analysis, comparing radium with operation, included on the side of radium the nine radium cures obtained in his inoperable cases. We must hereafter emphasize that we are primarily concerned at the present time with the results obtained in operable cancer of the cervix. The vital question is whether in this group operation should be superseded by radium. Comparative statistics must allow no deductions. They must include merely the total five-year cures in all the operable cases, whether subjected to treatment or not, that come to the clinic during a given period.

As seen in the accompanying table eight writers gave sufficient details to permit the calculation of the percentage of operable cases of cervical cancer cured by radium alone. A total of 415 yielded 131 cures, or 31.5 per cent. This is considerably less than the 45 to 50 per cent cures obtained in the treat- 
TABLE I

\begin{tabular}{|c|c|c|c|c|c|}
\hline NAME & $\begin{array}{l}\text { TOTAL } \\
\text { CASES }\end{array}$ & $\begin{array}{l}\text { 5-YEAE } \\
\text { CURES }\end{array}$ & $\begin{array}{l}\text { PER CENT } \\
\text { CURES }\end{array}$ & $\begin{array}{l}\text { OPERABLT } \\
\text { CASES }\end{array}$ & $\begin{array}{l}\text { RADIUM CURES } \\
\text { IN OPERABLE } \\
\text { CASES }\end{array}$ \\
\hline $\begin{array}{l}\text { v.Seuffert } \\
\text { (Munich) }\end{array}$ & 205 & 40 & $10.5 \%$ & 102 & 31 \\
\hline $\begin{array}{l}\text { Schaefer } \\
\text { (Berlin) }\end{array}$ & 282 & 50 & $17.7 \%$ & 155 & 43 \\
\hline $\begin{array}{l}\text { Weinbrenner } \\
\text { (Magdeburg) }\end{array}$ & 51 & 18 & $35.3 \%$ & 25 & 10 \\
\hline $\begin{array}{l}\text { Warnekros } \\
\text { (Berlin) }\end{array}$ & 173 & 39 & $22.5 \%$ & 96 & 34 \\
\hline $\begin{array}{l}\text { Heyman } \\
\text { (Stockholm) }\end{array}$ & 66 & 18 & $27.3 \%$ & 9 & 4 \\
\hline $\begin{array}{l}\text { Baisch } \\
\text { (Stuttgart) }\end{array}$ & 42 & 7 & $16 \%$ & 15 & 5 \\
\hline $\begin{array}{l}\text { Schweitzer } \\
\text { (Leipzig) }\end{array}$ & 49 & 4 & $8 \%$ & 8 & 2 \\
\hline $\begin{array}{l}\text { Dietrich } \\
\text { (Goettingen) }\end{array}$ & 26 & 4 & $15 \%$ & 5 & 2 \\
\hline $\begin{array}{l}\text { Recasens } \\
\text { (Madrid) }\end{array}$ & 126 & 32 & $25.4 \%$ & 一 & - \\
\hline $\begin{array}{l}\text { Ransahoff } \\
\text { (Cincinnati) }\end{array}$ & 30 & 3 & $10 \%$ & 一 & 一 \\
\hline $\begin{array}{l}\text { Gieseke } \\
\text { (Kiel) }\end{array}$ & 39 & 4 & $10.3 \%$ & & \\
\hline $\begin{array}{l}\text { Flatau } \\
\text { (Dresden) }\end{array}$ & 25 & 4 & $16 \%$ & - & $\cdots$ \\
\hline Totals & 1114 & 223 & & 415 & 131 \\
\hline
\end{tabular}

ment of operable cases alone by the Wertheim hysterectomy. If we take von Seuffert's more detailed report ${ }^{3}$ of the Doederlein elinic in Munich, we find that during the years 1908-1912, previous to taking up radium treatment, 167 operable cervical cancers presented themselves for treatment. Of these, 110 were early operable and 57 were advanced operable (borderline cases; 49 of the 110 early cases were cured by operation ( 44.5 per cent), whereas only 6 ont of the 57 advanced ones were cured (10.5 per cent). Comparing this with the radium results, he found that out of 102 operable cases in the years 1913-1914 17 out of 40 early cases were cured (42.5 pcr ecnt) while 14 out of 62 advanced ones were cured (22.5 per cent). This would seem to show that in the early operable group radium is somewhat inferior to operation, whereas in the advanced operable, or borderline group, radium cures almost twice as many as operation. The figures of Schaefer from Bumm's clinic in Berlin correspond closely : 33.7 per cent radium cures out of 74 early operable cancers and 23.4 per cent radium cures out of 81 borderline cancers.

To summarize then, it has been established that:

1. Inoperable as well as operable cervical cancer can be cured by radium alone for more than five years in a not inconsiderable number of cases (223 out of 1114).

2. The percentage of cures by radium about equals that of cures by operation (20 per cent).

3. The results with radium in the operable cases alone are still inferior to opcration, amounting to 31.5 per cent (131 out of 415 ) as enmpared with 45 to 50 per cent by operation. But closer analysis shows that while the percentage of operative cures is greater in the early operable group, the percentage of ractium cures is greater in the borderline group.

\section{REFERENCES}

(1) Fortschr. a. d. Geb. d. Roentg., 1913, xxi, 235. (2) Radiumtherapie, Paris, 1912. (3) Monatschr. f. Geburtsh. u. Gynäk., 1920, liii, 115. (4) Zentralbl. f. Gynäk., 1920, xliv, 
714. (5) Strahlentherapie, Berl. u. Wien., 1920, xi, I, 179. (6) Arch. mens, d'obst. et de gynéc., 1919, viii, 623. (7) Presse med., 1920, xxviii, 633. (S) Ugesk. f. Laeger, 1920, lxxxit, 357, rev. in Surg., Gynee. and Obst., 1920, xxxi, 396. (9) Strahlentherapie, x, 1, 45. (10) Monatschr. f. Geburtsh. u. Gynäk., 1920, lii, 137. (11) Zentralbl. f. Gynäk., 1919, xliii, 134. (12) Monatschr. f. Geburtsh. u. Gynäk., 1920, lii, 137. (13) Zentralbl. ł. Gynäk., 1920, xliv, 714. (14) Zentralbl. f. Gynäk., 1920, xliv, 687. (15) Strahlentherapie, Berl. u. Wien., 1920, x, 1, 37. (16) Strahlentherapie, Berl. u. Wien., 1920, x, 2, 854. (17) Zentralbl. f. Gynäk., 1920, xliv, 686. (18) Zentralbl. f. Gynäk., 1990, xliv, 719. (19) Zentralbl. f. Gynäk., 1920, xliv, 757. (20) Tr. Am. Gynee. Soc., 1916, xli, 532. (21) Tr. Am. Gynoc. Soe., 1919, xliv, 191. (22) Jour. Am. Med. Assn., 1920, Ixxiv, 163. (23) Am. Jour. Roentg., 1920, vii, 383. (21) Ann. Surg., lxxi, 683.

\section{Selected Abstracts}

\section{The Value of Roentgenography in Obstetrics}

\section{Warnekros: Pregnancy and Labor in Roentgen Pictures. Zeitschrift für} Geburtshülfe und Gynäkologie, 1918, lxxx, 719.

Advance in technic has made it possible to procure exact pictures of the fetus within the uterus by means of very short exposures of about eight to nine tenths of a second. By preparing series of pictures of the same patient in the coursc of pregnaney, and especially during the actual process of labor Warnekros was enabled to obtain "by direct observation" definite information concerning the normal attitude of the fetus during pregnancy, and what seems more important, concerning the mechanism of labor. Warnekros with some justification demands that wherever such observations do not harmonize with older views or theories, the latter now must be disearded as positively disproved. In regard to the normal attitude of the fetus he concludes: In the absence of a mechanical disproportion between fetus and uterus, and in the absence of any maternal or fetal abnormalities, the fetal head is held in a comfortable middle flexion. The fetal vertebral column in its convex bent is but conforming to the elliptoid shape of the uterus. There also is no forced or even typical attitude of the extremities. Their position depends solely upon the available space. This is true both for head and breech presentations. Any deviation from such a natural attitude suggests an anomaly of some sort. Even late in labor the fetus may change its position. The older conception that the presentation is dependent upon the stature of the mother is confirmed.

A thorough revision of views is required in regard to the mechanism of labor. Under normal conditions the head enters the pelvic canal without further increase in flexion. The extreme flexion occurs approximately at the time when internal rotation begins. This exaggeration of flexion clearly is the result of the pressure transmitted from the fundus by way of the vertebral column, which pushes the oceiput deeper down. The vertebral column straightens while the head passes through the pelvis. Internal rotation apparently occurs, as is generally taught, under the influence of the pelvic floor muscles. At the moment when the head is born, in contradiction to common opinion, the shoulders are still seen to stand transversely in their normal relation to the hcad. There is no torsion. The thorax is circularly constricted and drawn down in a funnel shape. These findings possibly corroborate the older view that the first inspiration is effected by the spontaneous expansion of the compressed thorax.

(This article contains but a few of the many excellent radiograms which have been published in form of an atlas by .J. F. Bergmann.) 